\title{
MIR509-1 wt Allele
}

National Cancer Institute

\section{Source}

National Cancer Institute. MIR509-1 wt Allele. NCI Thesaurus. Code C142765.

Human MIR509-1 wild-type allele is located in the vicinity of Xq27.3 and is approximately 94 bases in length. This allele, which encodes MIR509-1 pre-miRNA, plays a role in the modulation of target gene expression. 